\title{
THE EFFECT OF LEADERSHIP, EDUCATION AND COMMUNICATION CHANNEL FACTORS ON PATIENT SAFETY CULTURE
}

\author{
Tina Rahmawati ${ }^{*}$, Arif Satria ${ }^{* *}$, and Ninuk Purnaningsih ${ }^{* *}$ \\ *) RS Jantung dan Pembuluh Darah Harapan Kita \\ Jl. Letjen S. Parman Kav. 87 Slipi Jakarta Barat 11420 \\ **) Department of Communication Science and Community Development, Faculty of Human Ecology, \\ Bogor Agricultural University \\ IPB Darmaga Campus, Bogor 16680
}

\begin{abstract}
Organizational culture has an important role in improving patient safety. In order to improve the implementation of patient safety culture, management and organization culture need to be tranformed. The objectives of this study were to analyze patient safety culture among groups of units of the hospital and to analyze leadership, education, and communication channel related to patient safety culture. This study was based on surveys and data from Quota Random Sampling Method. The data processing for mean analysis of patient safety culture scores among groups of work units was conducted using ANOVA test while the analysis for the relationship of leadership, education, and communication channel with the patient safety culture was performed by using SEM Partial Least Square (PLS) application. The results show that safety patient culture has no significant differences among nursing work unit meanwhile, leadership and education give significant relations on patient safety culture, and communication channel has no significant relations. The patient safety culture that is evenly distributed among the nursing units is a strength for the organization, and the factors that influence the establishment of the patient safety culture on the nurses are leadership and education.
\end{abstract}

Keywords: patient safety culture, leadership, education, communication channel

\begin{abstract}
Abstrak: Budaya organisasi berperan penting dalam perbaikan keselamatan pasien. Untuk peningkatan budaya diperlukan pemahaman bagaimana budaya keselamatan pasien yang baik dan bagaimana mengukur dan memonitornya. Tujuan penelitian ini untuk menganalisis budaya keselamatan pasien pada perawat dan antar kelompok unit kerja keperawatan serta menganalisis pengaruh faktor kepemimpinan, pendidikan dan saluran komunikasi terhadap budaya keselamatan pasien pada perawat. Penelitian dengan metode survei dan pengambilan data melalui metode Quota Random Sampling. Pengolahan data untuk analisa rerata skor budaya keselamatan pasien antar kelompok unit kerja dilakukan dengan uji ANOVA sedangkan untuk analisa hubungan kepemimpinan, pendidikan/pelatihan, saluran komunikasi terhadap budaya keselamatan pasien dilakukan dengan menggunakan aplikasi SEM Partial Least Square (PLS). Hasil penelitian budaya keselamatan pasien pada perawat antar kelompok unit kerja keperawatan menunjukkan tidak terdapat perbedaan yang signifikan. Kepemimpinan dan pendidikan berpengaruh signifikan terhadap budaya keselamatan pasien. Namun saluran komunikasi tidak berpengaruh signifikan terhadap budaya keselamatan pasien. Budaya keselamatan pasien yang merata di seluruh unit keperawatan merupakan kekuatan bagi organisasi dan faktor yang berpengaruh terhadap pembentukan budaya keselamatan pasien pada perawat adalah kepemimpinan dan pendidikan.
\end{abstract}

Kata kunci: budaya keselamatan pasien, kepemimpinan, pemimpin transformasi, pendidikan, saluran komunikasi

${ }^{1}$ Corresponding author:

Email: tna_rahmawati@yahoo.com 


\section{INTRODUCTION}

The patient safety goal is a requirement to be applied in all hospitals accredited by the Hospital Accreditation Commission. The formulation of this objective refers to Nine Life-Saving Patient Safety Solutions from WHO Patient Safety in 2007 which is also used by the Patient Safety Committee of the PERSI Hospital (KKPRS PERSI) and Joint Commission International (JCI) (Kemenkes, 2011).

Increased patient safety through management has been a major problem since 2000 , where medical institutions are responsible for most medical errors (Kim and Bennett, 2012). Security risk management interventions deal with the coordination, resource allocation and standardization in health organizations, human resource management issues, communications, information technology, and improvement of interagency initiatives (Duckers et al. 2009). Organizational culture is a system of sharing actions, values and beliefs that exist in an organization and provides behavioral guidance for members of the organization. An effective organizational culture is critical to the success of new initiatives in patient safety (Schermerhorn et al. 2012). Although transformation of organizational culture is difficult, it is essential for improvements in patient safety. Low attention to culture is a problem, whereas it plays a role in improving safety. For cultural improvement, it is necessary to understand how good patient safety culture is and how to measure and monitor it (Yu et al. 2016).

Measurement of the culture of patient safety in an organization can have several internal sub-cultures and geographical variations that have high values in one aspect of safety culture; however, it can also have low values in others (WHO, 2008). In some cases, the culture of an organization can show a strong or a weak culture; however, there is a possibility of a sub-culture that brings together a small number of employees in the organization. This group can be formed because there is strong leadership in one area of the organization to create different norms and values, or it is able to act independently and creates their own culture (Colquitt et al. 2013). In addition, according to Jordan et al. (2015), leadership qualities are positively associated with the patient safety culture.

As standards and services become increasingly complex, education and training can complement healthcare staff and users with the knowledge, skills, attitudes, and behaviors required to perform safer care (Yu et al. 2016). Competence has a significant relationship to patient safety incidents (Mulyana, 2013), and high learning culture is positively associated with patient safety as well as interdisciplinary team action (Kim and Bennett, 2012). In addition, the patient safety standard also states that the planning and design of the patient's safety information management process are required to meet the needs of internal and external information.

In order to realize the satisfaction of key stakeholders (patients) in the form of effective, correct, safe, patient centered and one stop services are required. Nevertheless, the increasing needs for services where the number of patients is increasing affect the waiting time, and the treatment action takes longer. To that end, Hospital X established a mitigation program realization master plan construction of new buildings and facilities to solve the problems, and it is expected to provide more optimal services so that the needs of the community can be fulfilled. The fulfilment of the optimal service needs is related to the increasing need of the number of human resources in the hospital where the need of the number of nursing staff is the highest. The improvement of patient safety culture needs to support of service quality.

Based on the above background, the scope of this study includes the leadership, education, communication channels, and patient safety culture while the objectives of this study were to analyze the patient safety culture on the nurses and among groups of nursing work units; to analyze the influence of leadership factors, education, and communication channel on the patient safety culture by the nurses.

\section{METHODS}

This research used a descriptive approach with a survey method conducted on a nursing profession group in one special hospital (Hospital X) in Jakarta which becomes the national reference center. The data used in this research were quantitatively and qualitatively primary data. The quantitative data were obtained through questionnaires where the patient safety culture referred to the Agency for Healthcare Research and Quality (AHRQ), the leadership style referred to Williams (2014) research, education and communication channels referred to the Regulation of 
Ministry of Health (Permenkes) No. 1691 of 2011. The questionnaires were prepared using the Likert Scale (five scales) to find out the response scale of approval ("Strongly disagree" to "Strongly agree" or frequency ("Never" to "Always"). The established questionnaire was tested for its validity and reliability while the qualitative data were obtained through interviews and focus group discussions.

The sampling size referred to Slovin method with a fault tolerance level of $10 \%$ to obtain a minimum sample number (n) of 88 people. The sample selection (n) of 100 nurses was determined based on Quota Random Sampling method according to the proportion of nurses per work unit of service of the total 694 nurses (N) at the staff level and team leaders.

The data processing for mean analysis of patient safety culture scores among groups of work units was conducted by ANOVA test while the analysis for influence of leadership, education, and communication channel to the patient safety culture was performed by using SEM Partial Least Square (PLS) application.

In this research, the data processing with SEM PLS was conducted through the following stages: Evaluation on the initial model measurement; Evaluation on the model after elimination of variables; Evaluation on the structural model; Hypothesis testing of structural equation modeling with SEM PLS.

Research framework (Figure 1) showed that leadership style, education, and communication channel were the exogenous variables, and patient safety culture was the endogenous variable. Based on the research framework and problems pointed above, the research hypoteses are as follows:

Hypotesis 1

H0 : Leadership has no significant influences on patient safety culture

$\mathrm{Ha}$ : Leadership has significant influences on patient safety culture

Hypotesis 2

HO : Education has no significant influences on patient safety culture

$\mathrm{Ha}$ : Education has significant influences on patient safety culture

Hypotesis 3

H0 : Communication channel has no significant influences on patient safety culture

$\mathrm{Ha}$ : Communication channel has significant influences on patient safety culture

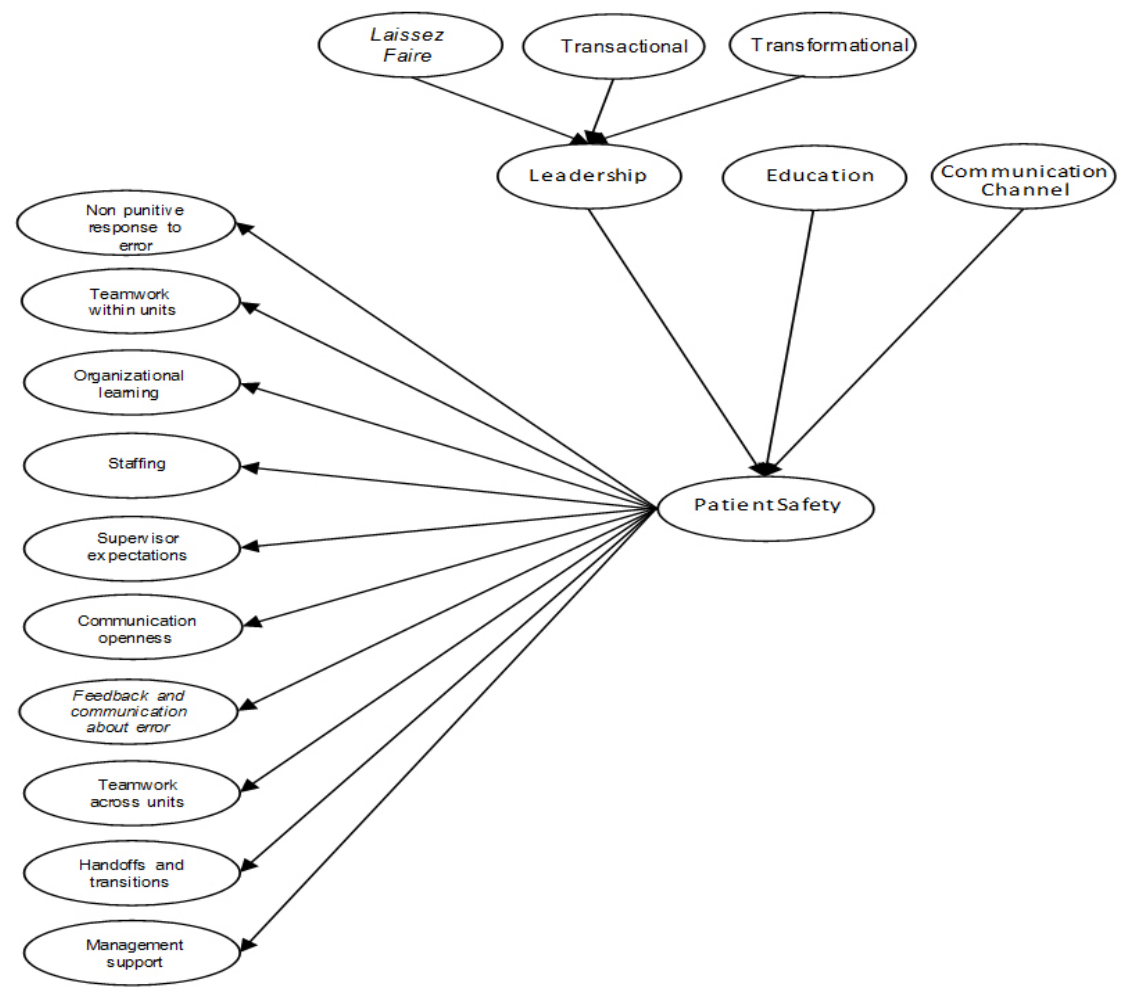

Figure 1. Research framework 


\section{RESULTS}

The study was conducted from April to September 2017 by first passing the ethical test stages by the Institutional Review Board (IRB)/Hospital Research Ethics Committee. A total of 100 respondents from the nursing units were grouped into four groups of work units according to the grouping of location value indexes i.e. group I (Ambulatory: general polyclinic), Group II (Average Care), Group III (Intermediate Care) and Group IV (Intensive Care).

The characteristics of the respondents in the study in Table 1 showed that most respondents were female. The highest level of education was graduate, and the longest period of work both in the hospital and units was above 10 years. The average of working hours in the units was 41 hours per week where the nurses generally work with shift work schedule, and the distribution level of competence of the respondents was between 20-30 people.

Table 2 showed the results of the study in terms of leadership style, education and communication channel. Leadership theory according to Bass and Riggio (2006) has three styles ofleadershipi.e. laissez-faire leadership, transactional and transformatio-nal styles. Leadership style showed laissez-faire style with an average score of 2.37 or $47 \%$ (medium category), transactional style with an average score of 3.73 or $75 \%$ (high category) and transformational style with an average score of 3.84 or $77 \%$ (high category). These results indicate that the dominant leadership style exists in transactional and transformational styles.

Education includes the relationship between the position and patient safety, ongoing education implementation to improve and maintain staff competencies to support interdisciplinary approach in patient care, and teamwork to support interdisciplinary and collaborative approaches in caring patients. The results of the survey related to the implementation of education on nurses showed a mean score of 4.17 or $83 \%$ (classified as the high category).

In this study, the communication channel illustrates the agreement toward the statement that the staff can easily find instructions in the form of symbols or information related to patient safety procedures in the work unit, and they can also understand the clarity of instructions in the form of symbols or information regarding safety procedures and the effectiveness of the incident reporting method in the event of errors. The result of the research related to communication channel showed an average score of 4.15 or $83 \%$ (high category).

Table 1. The demographic characteristic of respondents

\begin{tabular}{|c|c|c|c|c|c|c|}
\hline \multirow{2}{*}{ Characteristic } & \multirow{2}{*}{ Category } & \multicolumn{4}{|c|}{ Unit Group } & \multirow{2}{*}{$\begin{array}{r}\text { Total } \\
\mathrm{n}=100\end{array}$} \\
\hline & & $\mathrm{I}(\mathrm{n}=4)$ & II $(n=26)$ & III $(n=22)$ & IV $(n=48)$ & \\
\hline \multirow[t]{2}{*}{$\overline{\operatorname{Sex}}$} & - Male & 1 & 5 & 2 & 19 & 27 \\
\hline & - Female & 3 & 21 & 20 & 29 & 73 \\
\hline \multirow[t]{3}{*}{ Education Level } & - Undergraduate & 3 & 12 & 6 & 24 & 45 \\
\hline & - Graduate & 1 & 14 & 16 & 23 & 54 \\
\hline & - Postgraduate & 0 & 0 & 0 & 1 & 1 \\
\hline \multirow[t]{4}{*}{ Work Duration at Hospital } & $<1$ year & 0 & 0 & 0 & 0 & 0 \\
\hline & $1-5$ year & 0 & 1 & 5 & 2 & 8 \\
\hline & $6-10$ year & 0 & 4 & 9 & 12 & 25 \\
\hline & $\geq 11$ year & 4 & 21 & 8 & 34 & 67 \\
\hline \multirow[t]{4}{*}{ Work Duration at Unit } & $<1$ year & 0 & 1 & 0 & 0 & 1 \\
\hline & $1-5$ year & 2 & 7 & 5 & 6 & 20 \\
\hline & $6-10$ year & 0 & 6 & 11 & 16 & 33 \\
\hline & $\geq 11$ year & 2 & 12 & 6 & 26 & 46 \\
\hline Numbers of Working Hour / Week & & 42 & 41 & 42 & 41 & 41 \\
\hline \multirow[t]{4}{*}{ Competencies Level } & Beginner & 1 & 2 & 14 & 8 & 25 \\
\hline & Advanced Beginner & 1 & 9 & 4 & 16 & 30 \\
\hline & Competent & 2 & 8 & 0 & 15 & 25 \\
\hline & Proficient & 0 & 7 & 4 & 9 & 20 \\
\hline
\end{tabular}


Patient safety culture based on the Agency for Healthcare Research and Quality (AHRQ) is measured in 12 dimensions (Sorra et al. 2007). In reference to the previous research by Ghobashi et al. (2014), in this study, the culture was grouped into ten dimensions including non-punnitive respon to error, teamwork within center unit, organizational learning, continuous improvement, staffing, supervisor/manager expectations and actions promoting safety, communication openness, feedback and communication on error, teamwork across all center unita, center handoffs and transitions and center management support for patient safety while the other two dimensions included patient safety perception and incident reporting frequency.

Table 3 showed that the overall average score for the patient safety culture dimension was 3.85 or $77 \%$ and was included in the high category. The nine dimensions of the patient safety culture had a mean total score of 67\% (high category), including center management support for patient safety $(85 \%)$, center handoffs and transitions (75\%), teamwork across all center unit (79\%), feedback and communication on error (78\%), communication openness (70\%), supervisor expectations (75\%), learning organizations (82\%), teamwork within units (84\%) and non-punnitive respon to error $(76 \%)$ while one dimension included in the medium category with a total average score of $66 \%$ is the staffing dimension

The results of the research on the patient safety culture among the groups of nursing work units (Table 4) conducted with the analysis of variance (ANOVA) showed that there were no significant differences. The patient safety outcome in Table 5 includes the patient perception on safety, frequency of reporting and number of incident reports. The perception of patient safety based on the results of the study showed a mean score of 3.63 or $73 \%$ (high category). The reporting of patient safety incidents based on the Patient Safety Incident Reporting Guidelines (IKP) aims to reduce patient incidents (KTD, KTC, and KPC) and improve patient care and safety.

Table 2. Leadership style, education and communication channel

\begin{tabular}{lccc}
\hline Variable & Average score & Average score (\%) & Category \\
\hline Leadership Style & & & \\
- Laissez Faire & 2.37 & 47 & Average \\
- Transactional & 3.73 & 75 & High \\
- Transformational & 3.84 & 77 & High \\
Education / Training & 4.17 & 83 & High \\
Communication Channel & 4.16 & 83 & High \\
\hline
\end{tabular}

Table 3. Patient safety culture

\begin{tabular}{|c|c|c|c|}
\hline Description of patient safety culture dimensions & Average score & Average score $(\%)$ & Category \\
\hline Non-punitive response to error & 3.78 & 76 & High \\
\hline Teamwork within center unit & 4.21 & 84 & High \\
\hline Organizational learning continuous improvement & 4.09 & 82 & High \\
\hline Staffing & 3.32 & 66 & Average \\
\hline Supervisor/manager expectations and actions promoting safety & 3.73 & 75 & High \\
\hline Communication openness & 3.51 & 70 & High \\
\hline Feedback and communication on error & 3.92 & 78 & High \\
\hline Teamwork across all center units & 3.90 & 79 & High \\
\hline Center handoffs and transitions & 3.77 & 75 & High \\
\hline Center management support for patient safety & 4.24 & 85 & High \\
\hline Total & 3.85 & 77 & High \\
\hline
\end{tabular}

Category: High (68\% - 100\%); Average (34\% - 67\%); Low (0\% -33\%) 
Table 4. Patient safety culture between unit groups

\begin{tabular}{lcccccc}
\hline \multirow{2}{*}{ Description of patient safety culture dimensions } & Average & \multicolumn{4}{c}{ Unit Group } & \multirow{2}{*}{ score } \\
\cline { 3 - 5 } & 3.78 & I & II & III & IV & \\
\hline Non-punitive response to error & 4.21 & 4.50 & 3.77 & 3.70 & 3.79 & 0.704 \\
Teamwork within center units & 4.09 & 4.13 & 4.23 & 4.18 & 4.17 & 0.575 \\
Organizational learning continuous improvement & 3.32 & 3.92 & 3.18 & 3.27 & 3.06 & 0.209 \\
Staffing & 3.73 & 3.94 & 3.76 & 3.51 & 3.79 & 0.176 \\
Supervisor/manager expectations and actions promoting safety & 3.51 & 3.17 & 3.63 & 3.56 & 3.46 & 0.589 \\
Communication openness & 3.92 & 3.58 & 3.87 & 3.88 & 3.99 & 0.692 \\
Feedback and communication on error & 3.90 & 4.00 & 4.12 & 3.70 & 3.95 & 0.082 \\
Teamwork across all center unit & 3.77 & 3.69 & 3.85 & 3.72 & 3.75 & 0.454 \\
Center handoffs and transitions & 4.24 & 4.08 & 4.29 & 4.11 & 4.28 & 0.541 \\
\hline Center management support for patient safety & & & & &
\end{tabular}

Note: $\mathrm{P}$ value $>0.05$, no significant differences

Table 5. Outcome measures of patient safety culture

\begin{tabular}{lccc}
\hline \multicolumn{1}{c}{ Outcome Measures } & Average Score & Average Score (\%) & Category \\
\hline Overall perceptions of patient safety & 3.63 & 73 & High \\
Frecuency of event reporting among all staf & 3.06 & 61 & Average \\
\hline
\end{tabular}

Category: High (68\% - 100\%); Average (34\% - 67\%); Low (0\% -33\%)

The results showed that the frequency of incident reports had a mean score of 3.06 or $61 \%$ (medium category). The number of incident reports filled in and submitted based on the results of the research shown in Figure 2 showed that there were 3 reports in the last week of period, 9 reports in the last month, 17 reports in the last 3 months, 25 reports in the last 6 months and 32 reports in the last 12 months. The reports in this study were obtained from 43 respondents or as much as $43 \%$ of the total. In this research, there were three research hypotheses: the relationships between the leadership, education and communication channel factors and the patient safety culture based on the structural equation modeling with SEM PLS.

Figures 3 and Table 6 above showed the hypothesis testing where the patient safety culture was a dependent variable. The result showed that leadership had a load factor value of 0.552 and a T-count value of 4.778 (T-count $\geq 1.96$ ), indicating that there is a significant effect on the patient safety culture.

Education/training showed a load factor value of 0.285 and a T-count value of 2.153 (T-count $\geq 1.96$ ), indicating that there was a significant effect on the patient safety culture while the communication channel showed the value of load factor of 0.090 and the value of T-count of 0.741 (T-count $\geq 1.96$ ), meaning that there is no significant effect on the patient safety culture.
The patient safety culture based on the results of the study showed that the nine dimensions belonged to the high criterion and one dimension belonged to the moderate criterion. The dimensions of teamwork within work units, learning organizations and management support are three dimensions with the highest scores $(\geq 80 \%)$. A high teamwork culture is established with nurse education/training programs through group dynamics and team building at the time of orientation. In addition, Hospital $\mathrm{X}$ also runs the team building training as a regular program annualy for all employees with the aim of establishing an organizational culture such as good teamwork. Penelitian yang dilaksanakan oleh Yanli et al. (2013) menunjukkan bahwa kerjasama tim merupakan salah satu dimensi yang memberikan respon positif yang lebih tinggi.

The dimensions of organizational learning continuous improvement are high in line with the high average score of education implementation in nurses. The learning process through routine case surgery is conducted in each work unit as learning and improvement processes for staff in the unit. In addition, on every increase in the level of competence of the nurses, they are required to perform surgical cases associated with the work unit and according to the requirements of each competency level. 


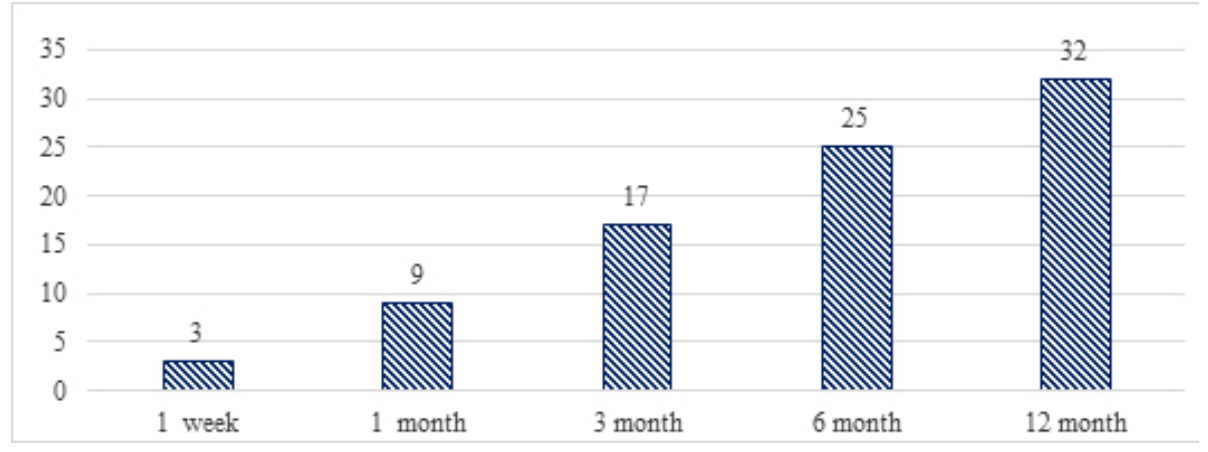

Figure 2. Event reporting

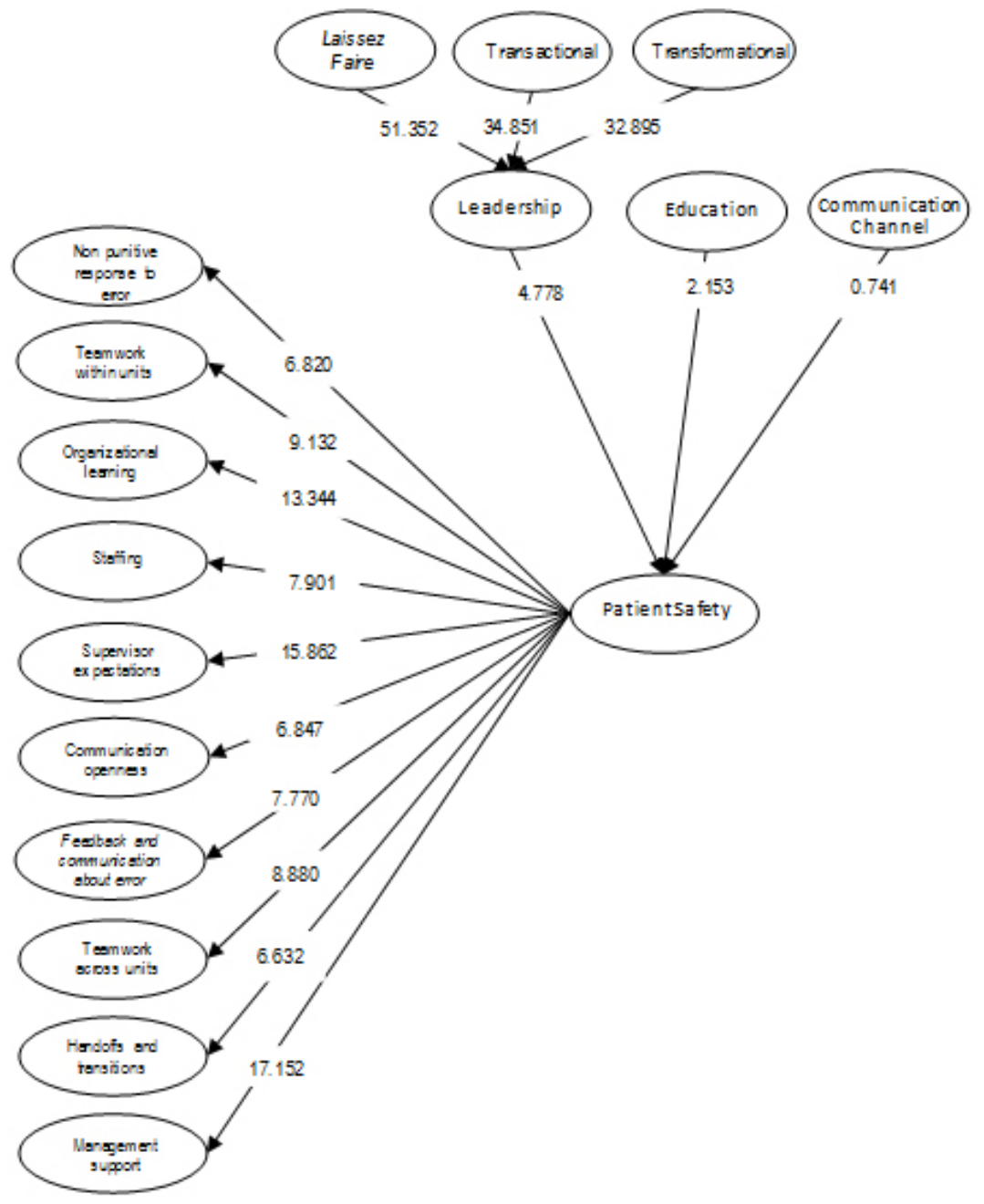

Figure 3. T-count after modification

Table 6 . The result of the hyphotesis testing on the patient safety culture

\begin{tabular}{lccc}
\hline \multicolumn{1}{c}{ Causality relationship (direct effects) } & Coefficient path & T-count & Conclusion \\
\hline Leadership style & 0.522 & 4.778 & Significant \\
Education/training & 0.285 & 2.153 & Significant \\
Communication channel & 0.090 & 0.741 & No Significant \\
\hline
\end{tabular}

Note: ${ }^{*}$ ) target of T-count $\geq 1.96$ (significant level of $5 \%$ ) 
The high dimension of management support is shown by the establishment of the organizational structure of the Quality and Risk Management Committee at the hospital. One is the Risk Management Sub-Committee responsible for patient safety. In the implementation of the work program of the Sub-Committee, a work group consisting of professional representatives and units related to patient safety as well as supported by the patient safety champion team were established. In addition to improving the quality of service, one effort is made through the accreditation program both at the National and International levels. The KARS accreditation of the 2012 version was obtained in 2015, and the International Accreditation Joint Commission International (JCI) was obtained in 2016.

The result of the staffing culture dimension showed the average score of $66 \%$ which is at the lowest position. Staffing in this case illustrates the notion that there are enough staff to handle the proper workload and working hours in providing the best care for the patient. Based on the results of the survey and confirmation with several nurses in the field, it was found out that there was still a workload that has not been optimal due to lack of staff.

The placement of staff in the work unit is carried out by considering the composition of the competency level and condition of the patient, ratio of the number of patients (occupancy rate/BOR), nurse on leave, education, and etc. However, in the implementation, there are still some obstacles. To overcome the problems of workforce in the work unit, generally Special Duty Nurse (SDN) assignment is given where the nurse obtains an additional duty outside her schedule of service. The arrangement of bed composition is also conducted to regulate the service requirement according to the complexity of the patient. Furthermore, the arrangement of staff is conducted by applying the rotation among the work units.

Based on Figure 4, we can see that the composition of nurse age in Hospital $\mathrm{X}$ and the data of the outgoing nurses from 2014 to 2017. In the age group of 25-34 years, it is the largest group where in this age group most of them request for the maternity leave. In addition, these data from 2014 to 2017 showed a picture of an increase in the number of outgoing employees either they enter the retirement age limit (BUP) or the retirement age beyond the limit (non BUP), and such conditions may cause additional workload of the employees.

The number of the outgoing employees entering the retirement age limit has been estimated on the plan to add employees in the current year. However, if the outgoing employees are entering the retirement age beyond the limit, the addition of new employees is not included in the plan in the current year. In addition, a new nurse requires to follow the education/training stage in order to meet the appropriate competencies; therefore, replacing the outgoing nurses requires a considerable large amount of process and investment.

The research conducted in several countries also showed a similar thing where the placement of staff is the dimension that occupies the lowest position. The research in Japan by Fujita et al. (2014) indicates that "staffing" had a mean score of $44 \%$ and "handoffs and transition" had a mean score of $41 \%$. The research in Saudi Arabia by El-Jardali et al. (2014) showed that "non-punitive response" obtained a mean score of $26.8 \%$, "staffing" of $35.1 \%$ and "communication openness" of $42.9 \%$.
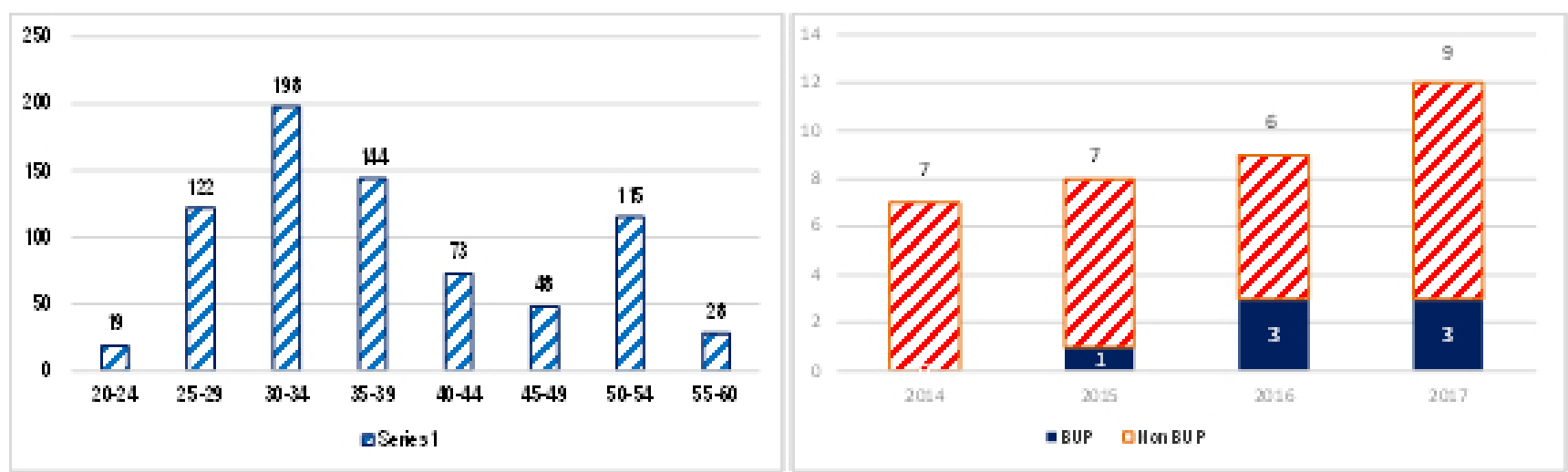

Figure 4. Data of the outgoing employees in the periode of 2014-2017 and the composition of the nurse age group 
The research in Kuwait, conducted by Ghobashi et al. (2014), indicates the "non-punitive response on errors" with a mean score of $24 \%$, "staffing" of $41 \%$ and "communication openness" of $45 \%$. In contrast, the research in the Netherlands (Smits et al. 2008) shows that "staff placement" does not include the cultural dimension of patient safety in the lowest position but includes it in the third highest position (74.6\%) after "teamwork in the work unit" and "openness of communication".

In this study, the patient safety culture among the groups of work units showed that there were no significant differences. Therefore, this is a strength for the organization, in which a good culture should be uniform on every unit in the organization. According to Colquitt et al. (2013), a strong culture showed the unity of employees. Meanwhile, a weak culture is seen when employees are not in line with what should be done and what is expected, which means there is no coherence in attitudes and actions. The formation of a strong culture takes a long time and is difficult to change. A strong culture directs employee attitudes and behaviors, yet it does not necessarily lead to the success of the organization.

Unlike the research case of Fujita et al. (2014), it indicates that there is a patient safety culture that varies among different types of work units in a hospital categorized into high and low PSC (Patient Safety Culture) units.

The results showed that patient perception of safety is classified as the high category and frequency of report is classified as the medium category. The number of incident reports in this research is based on reports that have been filled in and submitted by 43 respondents or $43 \%$ consisting of unit I ( 2 reports), unit II (6 reports), unit III (14 reports), and unit IV (21 reports). This indicates that reporting culture is high in nurses in which reporting an incident is considered important as the beginning of learning process to prevent or avoid incidents.

Howell et al. (2015) showed no association among the hospital sizes, number of employees, impacts of death or patient satisfaction and rate of incident reports. The results also indicate that hospital court prosecutions decrease if the staff report more incidents. Also the increase of the incident reports of injured patients, an open environment and reduction of fear of a punishment response may also increase the incident reports. Therefore, the level of reporting is not an indication to measure patient safety in a hospital. The research by Anggraeni et al. (2016) shows that the simultaneous results of patient safety culture have a significant effect on the attitude of reporting incidents.

In addition, Gunawan et al. (2015) stated that the low number of patient safety incidents does not reflect the actual conditions. The main causing problem is the lack of staff's understanding on the IKP caused by the fear of the consequences resulted from reporting the IKP.

The leadership style and implementation of education on nurses in X Hospital are in high category and indicates that both are significant factors (T-count $\geq$ 1.96) affecting the patient safety culture (Table 6).

Laissez faire leadership style showed the value of load factor of 0.906 , transactional of 0.912 and transformational of 0.920 . Subsequently, based on the descriptive data (Table 2) and the value of load factor, it indicates that the transformational leadership style of the nurses in X Hospital is the most dominant factor. This is in line with the result of the previous research by Meng (2014) stating that excellent leadership also produces a strong positive influence on organizational culture. In addition, Jordan et al. (2015) argued that there are positive transformational leadership and organizational culture in the intensive care unit and a strong positive correlation among the transformational leadership, organizational culture, and organizational change outcomes.

According to Mulyati et al. (2016), the leader perception is the determinant factor of the creation of patient safety culture; therefore, leadership style, communication technique, and managerial leadership ability are great concerns in creating a conducive working atmosphere as an effort to create a patient safety culture. The research by Anugrahini et al. (2010) also shows that leadership is one factor that influences nurse compliance toward patient safety guidelines.

The results showed that the implementation of education on nurses in X Hospital has an average score of $83 \%$ (high category) in which it is supported by interviews that showed a positive image on the implementation of education/training. Implementation of training and 
education in X Hospital refers to the Manual of Training and Development of Human Resources in which provisions concerning both domestic and overseas formal education, professional certified training, nonprofessional certified training, and special certified compulsory training are required. Special certified compulsory training is conducted to support the quality and safety program.

In addition, the Decree of the President Director No. YM.01/I/0144/2009 dated 14 September 2009 on the Implementation of Nurse Recruitment Guidelines covers the compulsory requirements for nurses; starting from the recruitment to the appointment as fulltime employees through the stages of education/ training i.e. Preceptorship Phase I, Preceptorship Phase II, Cardiology Basic, Preceptorship Phase III, and Preceptorship IV. In addition, leadership evaluation and nursing care plans are also the requirements prior to the appointment of permanent employees.

This is in line with the results of the research by Yulia et al. (2012) demonstrating that following the patient safety training by the nurses led to improved understanding of the nurses on patient safety practices affected by cognitive changes during the training process. In relation to the implementation of the Preceptorship program in X Hospital, the result of the research by Suryani et al. (2015) indicates that there is a significant relationship between the role of clinical counselors and the implementation of patient safety by the nurse students. In addition, Nygren et al. (2013) stated that training and education related to patient safety were identified as other important factors to achieve improved patient safety in the future.

Meanwhile, the result showed that communication channel has no significant effect on patient safety culture; although based on the descriptive data, it is included in the high category. The correlation of latent communication channel with patient safety culture shown in Table 6 highlights the value of load factor by 0.090 and T-count value by 0.741 (T-count $\geq 1.96$ ). Hence, this means that there is no significant relationship in which the variable of communication channel cannot significantly shape the perception of the patient safety culture of the nurses.

\section{Managerial Implications}

Patient safety culture based on analysis of mean value and loading factor shows that "supervisor/manager expectations and patient safety promotion actions" and "employee placement" in nurses are cultural dimensions that need to be prioritized for improvement while "central management support for patient safety", "teamwork in the work unit" and "learning organization and continuous improvement" are the best dimensions and need to be maintained

\section{CONCLUSIONS AND RECOMMENDATION}

\section{Conclusions}

The conclusion obtained from this study is that the patient safety culture on nurses shows no significant differences among the groups of nursing work units. Subsequently, this is a strength for the organization. Leadership and education/training are the influencing factors on the patient safety culture of the nurses in $\mathrm{X}$ Hospital. Even though the communication channel is adequate, this study shows no effects on the patient safety culture.

\section{Recommendations}

The measurements of further researches related to surveys on patient safety culture can be conducted not only based on staff perceptions but also on consumer reports regarding hospital safety scores. Therefore, it is expected to obtain a depiction of research results on more complete and more consumer-directed patient safety culture.

\section{REFERENCES}

Anggraeni D, Ahsan, Azzuhri M. 2016. Pengaruh budaya keselamatan pasien terhadap sikap melaporkan insiden pada perawat di Instalasi Rawat Inap Rumah Sakit Tk. II dr. Soepraoen. Jurnal Aplikasi Manajemen (JAM) 14(2): 309321.

Anugrahini C, Sahar J, Mustikasari. 2010. Kepatuhan perawat menerapkan pedoman patient safety berdasarkan faktor individu dan organisasi. Jurnal Keperawatan Indonesia 13(3):139-144. 
Bass BM, Riggio RE. 2006. Transformational leadership. Second Edition. New Jersey: Lawrence Erlbaum Associates Inc, Publishers.

Colquitt JA, Lepine JA, Wesson MJ. 2013. Organizational Behavior: Improving Performance and Commitment in The Workplace. Third Edition. New York : McGraw Hill.

Dückers M, Faber M, Cruijsberg J, Grol R, Schoonhoven L. 2009. Safety and Risk Management in Hospitals. IQ Scientific Institute for Quality of Healthcare, Radboud University Nijmegen Medical Centre.

El-Jardali F, Sheikh F, Garcia NA, Jamal D, Abdo A. 2014. Patient safety culture in a large teaching hospital in Riyadh: baseline assessment, comparative analysis and opportunities for improvement. BMC Health Services Research, 14, 122. https://doi.org/10.1186/1472-6963-14122.

Fujita S, Seto K, Kitazawa T, Matsumoto K, Hasegawa T. 2014. Characteristics of unit-level patient safety culture in hospitals in Japan: a crosssectional study. BMC Health Services Research, 14,508. https://doi.org/10.1186/s12913-0140508-2.

Ghobashi MM, El-ragehy HEG, Mosleh H, Al-Doseri FA. 2014. Assessment of patient safety culture in primary health care settings in Kuwait. Epidemiology Biostatistics and Public Health, 11(3):1-9.

Gunawan, Widodo FY, Harijanto T. 2015. Analisis rendahnya laporan insiden keselamatan pasien di rumah. Jurnal Kedokteran Brawijaya 28(2): 206-213.

Howell AM, Burns EM, Bouras G, Donaldson LJ, Athanasiou T, Darzi A. 2015. Can patient safety incident reports be used to compare hospital safety? Results from a quantitative analysis of the English National Reporting and learning system data. PloS One 10(12). https://doi.org/10.1371/ journal.pone.0144107.

Jordan PJ, Werner A, Venter D. 2015. Achieving excellence in private intensive care units: The effect of transformational leadership and organisational culture on organisational change outcome. SA Journal of Human Resource Management 13(1): 1-10.

[Kemenkes] Kementerian Kesehatan RI. 2011. Peraturan Menteri Kesehatan Republik Indonesia Nomor 1691 Tahun 2011 tentang Keselamatan Pasien Rumah Sakit. Jakarta:
Kementerian Kesehatan RI.

Kim YM, Bennett DN. 2012. The role of leadership in learning culture and patient safety. International journal of organization theory and behavior 15(2):151-175. https://doi.org/10.1108/IJOTB15-02-2012-B001.

Meng J. 2014. Unpacking the relationship between organizational culture and excellent leadership in public. Journal of Communication Management 18(4): 363-385. https://doi.org/10.1108/JCOM06-2012-0050.

Mulyana DS. 2013. Analisis penyebab insiden keselamatan pasien oleh perawat di unit rawat inap rumah sakit X di Jakarta [Tesis]. Universitas Indonesia.

Mulyati L, Rachman D, Herdiana Y. 2016. Faktor determinan yang mempengaruhi budaya keselamatan pasien di RS pemerintah kabupaten Kuningan. Jurnal Keperawatan Padjajaran 4(2): 179-190. https://doi.org/10.24198/jkp.v4n2.8.

Nygren M, Roback K, Öhrn A, Rutberg H, Rahmqvist M, Nilsen P. 2013. Factors Influencing Patient Safety In Sweden: Perceptions Of Patient Safety Officers In The Country Councils. BMC Health Services Research 13:52. https://doi. org/10.1186/1472-6963-13-52.

Schermerhorn JR, Osborn RN, Uhl-Bien M, Hunt JG. 2012. Organizational Behavior (12th ed.). John Wiley \& Sons Pte Ltd.

Suryani L, Handiyani H, Hastono SP. 2015. Peningkatan pelaksanaan kese-lamatan pasien oleh mahasiswa melalui peran pembimbing klinik. Jurnal Keperawatan Indonesia 18(2): 115-122. https://doi.org/10.7454/jki.v18i2.412.

Sorra J, Nieva V, Famolaro T, Dyer N. 2007. Hospital survey on patient safety culture. Agency for Healthcare Research and Quality. AHRQ No. 07-0025.

Smits M, Dingelhoff IC, Wagner C, Van der Wal G, Groenewegen PP. 2008. The psychometric properties of the 'hospital survey on patient safety culture in Dutch Hospitals. BMC Health Services Research 8:230. https://doi.org/10.1186/14726963-8-230.

Williams JC.2014. Nurses' organizational commitment, job satisfaction, and perception of their managers' leadership style as predictors of perception of patient safety culture [Dissertation]. Capella University.

[WHO] World Health Organization. 2008. Summary of the evidence on patient safety: implications for 
research. WHO Press.

Yanli N, Xuanyue M, Hao C, Shenghong H, Jing L, Mingming Z. 2013. Hospital survey on patient safety culture in China. BMC Health Services Research 13 : 228. https://doi.org/10.1186/14726963-13-228.
Yu A, Flott K, Chainani N, Fontana G, Darzi A. 2016. Patient Safety 2030. London: NIHR.

Yulia S, Hamid AYS, Mustikasari. 2012. Peningkatan pemahaman perawat pelaksana dalam penerapan keselamatanpasienmelaluipelatihankeselamatan pasien. Jurnal Keperawatan Indonesia 15(3): 185-192. 